\title{
KEBUTUHAN INFORMASI GAYA HIDUP REMAJA TENTANG FASHION DI SEKOLAH MENENGAH PERTAMA NEGERI 21 BEKASI
}

\author{
Irmay Widyastuti ${ }^{1}$, Dr. Hj. Tine Silvana Rachmawati, M.Si ${ }^{2}$, Nuning Kurniasih ${ }^{3}$ \\ ${ }^{1}$ PT Pelangi Cimandiri Textile, ${ }^{2,3}$ Program Studi Ilmu Perpustakaan Fikom Unpad \\ 1.
}

\begin{abstract}
The purpose of doing this research is to know the information necessity of teenager's lifestyle about fashion in 21 state junior high school of Bekasi. This research was doing on December 2013 until March 2014. This research using qualitative method to explore and understand the sense of information necessity of teenager's lifestyle about fashion. This research process was doing from the process of information necessity of teenager's observe from an individual internal factor until the fulfillment necessity efforts about to information teenager's lifestyle observation from individual external factor aggregation technique of data is using observation interview, and research study. The result from the research know about the student has followed the information about fashion development by internet, they can fulfill necessity them information. The conclusion from this research there are: 1. generally the student automatically looked for information whatever their necessity to support in lifestyle; 2. generally they filtered the appropriate information with culture where they are from; 3. Motive the student in fulfill information necessity usually they want to know from internet or other media; 4. Connection of teenager's and other people around them also influence the teenager's and other people around them also influence the teenager's in fulfill the necessity of their information.
\end{abstract}

Keywords: Information Necessity of Teenager's, Fulfill Necessity of Information, Search of Information

ABSTRAK - Tujuan melakukan penelitian ini adalah untuk mengetahui kebutuhan informasi gaya hidup remaja tentang fashion di SMP Negeri 21 Bekasi. Penelitian ini dilakukan pada Desember 2013 sampai Maret 2014. Penelitian ini menggunakan metode kualitatif untuk menggali dan memahami arti kebutuhan informasi gaya hidup remaja tentang fashion. Proses penelitian ini dilakukan melalui proses kebutuhan informasi dari mengamati remaja berdasarkan faktor internal individu sampai upaya pemenuhan kebutuhan akan observasi gaya hidup informasi remaja dari teknik agregasi faktor eksternal individu menggunakan wawancara observasi, dan studi penelitian. Hasil dari penelitian mengetahui siswa telah mengikuti informasi tentang perkembangan fashion dari internet, itu dapat memenuhi kebutuhan informasi mereka. Kesimpulan dari penelitian ini yaitu: 1 . umumnya siswa secara otomatis mencari informasi apapun kebutuhan mereka untuk mendukung gaya hidup; 2. umumnya mereka menyaring informasi yang sesuai dengan budaya darimana mereka berasal; 3. biasanya motif siswa memenuhi kebutuhan informasi mereka ingin tahu dari internet atau media lainnya; 4. Keterkaitan remaja dan orang-orang lain di sekitar mereka juga mempengaruhi memenuhi kebutuhan informasi mereka.

Kata kunci: Kebutuhan Informasi Remaja, Pemenuhan Kebutuhan Informasi, Pencarian Informasi

\section{PENDAHULUAN}

Di kota-kota besar, seringkali kita melihat kelompok remaja yang setia mengikuti perkembangan mode, yang sudah pasti datangnya dari luar. Media masa merupakan wadah yang paling besar keterlibatannya dalam mempengaruhi remaja. Transformasi budaya ini, dilihat oleh remaja sebagai sesuatu yang menyenangkan, gambaran manusia modern dan tidak mempedulikan lagi kaidah-kaidah agama dalam berbusana.

Pada masa puber ini remaja berada pada tahap pencarian jati diri untuk mencari identitas diri. Dalam rangka untuk menemukan identitas diri 
tersebut maka remaja membutuhkan informasi. Di negara kita masa puber terjadi pada mereka yang berada di Sekolah Menengah Pertama (SMP). Salah satu sekolah dimana para siswanya sudah memenuhi kebutuhan informasinya tentang gaya hidup terutama fashion yaitu Sekolah Menengah Pertama Negeri 21 Bekasi. Pada sekolah ini, para siswanya sudah mengikuti perkembangan trend mode fashion, ini terlihat ketika penulis melakukan penelitian pada saat SMP tersebut sedang melakukan kegiatan study tour.

Remaja di Sekolah Menegah Pertama Negeri 21 Bekasi, mereka sudah mengikuti perkembangan fashion yang sedang berkembang sekarang ini, namun mereka mengaplikasikannya ketika sudah berada di luar sekolah. Karena sekolah sendiri sudah memiliki peraturan dimana mewajibkan untuk para Fashion (mode) merupakan suatu cara aksi yang dirangsang oleh perkembangan industri konsumen. Dinamika perubahan dalam cara-cara fashion yang berbeda begitu jelas mencerminkan proses pembentukan gaya hidup yang lebih luas. Fashion menegaskan identitas sosial seseorang dan secara bersamaan membiarkan individu membedakan dirinya dari yang lain. Bagi remaja, setiap tawaran gaya hidup akan disambut dengan sangat antusias siswanya menggunakan atribut sekolah yang telah ditentukan.

\section{TINJAUAN PUSTAKA}

Kebutuhan akan informasi dirasakan akan terus bertambah bagi seseorang setiap kali ia memiliki rasa ingin tahu yang tinggi terhadap sesuatu dan memiliki tujuan yang ingin ia capai. Tidak ada seorang pun yang tidak membutuhkan informasi, apapun jenis pekerjaan orang itu. Gaya hidup merupakan informasi yang berkaitan dengan kegiatan ekstrakulikuler, kerja paruh waktu, uang, olahraga, film dan rekreasi atau hiburan lainnya (Agosto and Hughes-Hassell, 2005). Gaya hidup remaja di Indonesia mengalami perubahan yang disebabkan oleh pola pikir masyarakat kota besar yang menghendaki kehidupan yang sebebas- bebasnya sehingga budaya-budaya asing yang tidak sesuai dengan kebudayaan kita mudah masuk dan berkembang dengan cepat.

Faktor-faktor yang mempengaruhi gaya hidup adalah:

\section{Faktor Internal}

Faktor-faktor yang mempengaruhi gaya hidup individu, yang berasal dari dalam diri individu tersebut antara lain adalah:

a) Persepsi

Persepsi adalah aktivitas yang membuat individu dapat mengartikan stimuli yang disajikan kepadanya.

b) Belajar dan ingatan.

Kita mendapatkan sebagian besar dari sikap, nilai, selera, tingkah laku, preferensi, arti simbolik, dan perasaan kita melalui belajar, yang juga sangat dipengaruhi oleh memori atau ingatan,

c) Motif, Kepribadian, dan Emosi.

Motif merupakan suatu kekuatan yang mengarahkan tingkah laku.Motif terdiri dari motif fisiologis dan motif psikologis. Motif psikologis dapat mendorong seseorang memperkuat konsep dirinya.

Kepribadian adalah karakteristik kecenderungan respon individu terhadap situasi yang serupa. Kepribadian memandu dan mengarahkan tingkah laku yang dipilih untuk mencapai tujuan dalam berbagai situasi. Emosi adalah perasaan 
subjektif yang dapat mempengaruhi persepsi, pikiran, dan tingkah laku seseorang.

\section{Faktor Eksternal}

Faktor-faktor yang berasal dari lingkungan individu yang pada akhirnya mempengaruhi gaya hidup individu adalah:

a) Budaya

Budaya dalam hal ini membatasi tingkah laku individu dan mempengaruhi fungsi institusi seperti struktur keluarga dan media massa. Disamping itu, budaya juga menyediakan kerangka yang di dalamnya berkembang gaya hidup individu.

b) Subkebudayaan

Subkebudayaan adalah bagian dari suatu kebudayaan inti dimana para anggotanya mempunyai pola tingkah laku unik yang didasari oleh sejarah sosial dari kelompok tersebut dan situasi yang sedang terjadi. Subkebudayaan terbagi- bagi berdasarkan etnis, ras, kebangsaan, agama, daerah, dan usia.

c) Nilai/values

Nilai didukung oleh suatu pola budaya dan dalam nilai budaya tersebut terdapat norma, dan sanksi yang akan mempengaruhi gaya hidup. (Hawkins, Best dan Coney, 1995)

Ditinjau dari psikologi perkembangan, maka remaja adalah sekelompok kaum muda dalam suatu kurun waktu tertentu. Gambaran mereka tentang dunia masih belum terbentuk secara kuat, oleh karena itu, mereka sangat peka terhadap propaganda dan mudah dipengaruhi.

\section{METODE PENELITIAN}

Penelitian kualitatif merupakan metodemetode untuk mengeksplorasi dan memahami makna yang oleh sejumlah individu atau sekelompok orang dianggap berasal dari masalah sosial atau kemanusiaan. Proses penelitian kualitatif ini melibatkan upaya-upaya penting, seperti mengajukan pertanyaan- pertanyaan dan prosedur, mengumpulkan data yang spesifik dari para informan, menganalisis data secara induktif mulai dari tema-tema yang khusus ke tema-tema yang umum, dan menafsirkan makna data (Creswell, 2010).

Metode kualitatif adalah sebuah proses penelitian dari pemahaman berdasarkan pada perbedaan tradisi metodologi penelitian yang menggali sebuah masalah sosial atau masalah manusia. Peneliti membangun sesuatu kekompleksan, gambaran menyeluruh, analisa kata-kata pelaporan secara rinci dari para informan, dan melakukan studi dalam situasi yang natural. (Cresswell dalam Rahardi 2007, 54).

\section{HASIL DAN PEMBAHASAN}

\section{Kebutuhan Informasi Gaya Hidup Remaja} Ditinjau Dari Faktor Internal Individu di SMPN 21 Bekasi

Informasi tentang gaya hidup terutama fashion juga banyak sekali ditampilkan di majalah-majalah remaja, seperti Gadis, Go Girl, dsb. Berbagai usaha sosialisasi yang dilakukan oleh media tentang gaya hidup, ternyata memang baik secara langsung maupun tidak langsung dapat mempengaruhi para remaja untuk meni- runya. Pengaruh media massa juga sangat besar dalam mempengaruhi para remaja dalam mengakses informasi tentang gaya hidup. Apalagi sekarang ini beberapa stasiun televisi mena- yangkan sinetron pada waktu siang atau malam hari. Pada acara 
televisi tersebut semua pemeran artis yang berperan memiliki gaya berpakaiannya masing-masing.

Umumnya para informan melakukan interaksi dengan lingkungan sekitar atau teman sebayanya untuk memperoleh informasi. Dengan meningkatnya interaksi sosial dengan teman sebaya, pengaruh mereka bertambah pula. Tetapi pada waktu anak- anak masuk sekolah, mereka belajar bahwa tingkah laku mereka dikendalikan oleh peraturan sekolah. Dan secara langsung ataupun tidak langsung, para remaja memiliki artis idolanya untuk mengikuti gaya berpakaian mereka dari artis idiolanya tersebut.

\section{Kebutuhan Informasi Gaya Hidup Remaja Ditinjau Dari Faktor Eksternal Individu di SMPN 21 Bekasi}

Kebutuhan infomasi gaya hidup remaja sekarang ini sudah sangat berkembang secara cepat dikarenakan zaman yang semakin modern. Informasi tersebut sudah mudah diakses melalui internet. Para informan mengatakan bahwa sekarang ini perkembangan fashion sudah dipengaruhi dari budaya luar yang disebarluaskan melalui internet, televise, atau majalah. Namun para informan dapat melakukan pemilihan informasi terhadap perkembangan fashion yang telah dipengaruhi budaya luar tersebut, mereka memilih fashion yang cocok untuk kebudayaan Indonesia. Para informan seringkali mengaplikasikan gaya berpakaiannya ketika berada di luar sekolah. Karena sekolah memiliki peraturan yang berhak mengatur mereka agar mereka disiplin tetap berada pada norma budaya Indonesia. Status dapat mempengaruhi kepribadian dengan jalan mempengaruhi konsep diri, anak harus sadar akan lambang manakah yang dihargai kelompok sosial dengan siapa mereka diidentifikasikan, dan harus sadar bahwa mereka dinilai berdasarkan lambang status yang dia miliki dan keluarganya.

\section{Upaya Pemenuhan Kebutuhan Akan} Informasi Gaya Hidup Para Remaja Ditinjau Dari Faktor Internal Individu di SMPN 21 Bekasi

Dalam proses pemenuhan kebutuhan informasi, informan memerlukan sumber informasi. Semua informan mengungkapkan bahwa mereka kebanyakan memenuhi kebutuhan informasinya menggunakan internet dan majalah. Para informan mengungkapkan bahwa dirinya lebih suka mencari informasi di internet. Kepraktisan dan daya tarik yang ditawarkan oleh internet membuat informan lebih menyukai internet dibandingkan dengan buku. Informasi yang diperoleh dari internet seperti informasi tentang peristiwa atau berita terkini, hiburan, kesehatan, kecantikan, informasi yang dibutuhkan untuk mengerjakan tugas dan informasi lainnya. Efek dari media massa sering diperdebatkan karena para remaja lebih banyak menghabiskan waktunya dengan media massa dari pada dengan sekolah atau orang tuanya, media massa penuh dengan gambaran yang mengagungkan kehidupan orang dewasa beresiko tinggi seperti kekerasan dan lainnya. Saat ini, rata-rata para informan akan menghabiskan waktu lebih banyak untuk menonton TV daripada aktivitas lainnya kecuali aktivitas tidur. Di duga, remaja lebih mudah terkena dampak negative secara langsung dari media massa.

\section{Upaya Pemenuhan Kebutuhan Akan}

\section{Informasi Gaya Hidup Para Remaja Ditinjau}

\section{Dari Faktor Eksternal Individu di SMPN 21}

Proses modeling atau mengikuti contoh adalah proses dimana khalayak media massa mengikuti cara berperilaku seperti tokoh dan informasi yang 
didapatkannya di media massa. Hal ini memang tidak lepas dari perkembangan remaja secara keseluruhan yang dapat dilihat dari aspek psikologisnya dengan menggambarkan bahwa masa remaja mempunyai kecenderungan yang kuat menemukan contoh untuk ditiru dan diidentifikasi. (Gunarsa, Singgih D., 1986, 210). Para informan di SMPN 21 Bekasi juga mengatakan bahwa mereka suka melihat idolanya di televisi dan terkadang mereka juga mengikuti gaya berpakaiannya. Selain itu, para informan dalam memenuhi kebutuhan informasinya, mereka mendapatkannya melalui teman sekelompoknya atau teman sebayanya. Biasanya mereka memenuhi kebutuhan infor- masinya melalui teman sebayanya dikarenakan mereka berada di keadaan yang sama, yaitu sama-sama mencari jati diri atau identitas diri.

\section{SIMPULAN}

Kesimpulan yang diambil dalam penelitian ini adalah kesimpulan yang berdasarkan hasil observasi dan hasil wawancara yang diperoleh dari informan. Dari hasil pembahasan pada sebelumnya, dapat ditarik kesimpulan bahwa:

1. Kebutuhan informasi gaya hidup remaja pada masa puber ditinjau dari faktor internal berkaitan dengan masa pencarian jati diri dan krisis identitas yang sedang dialami remaja, sehingga remaja lebih membutuhkan informasi yang berkaitan dengan dirinya sendiri untuk menemukan jati dirinya. Terbukti dengan informasi yang dibutuhkan oleh remaja adalah informasi yang berkaita dengan gaya hidup. Menurut penelitian yang telah dilakukan, umumnya para informan sudah otomatis mencari sendiri informasi apa saja yang ia butuhkan dalam menunjang gaya hidupnya.
2. Kebutuhan informasi gaya hidup remaja ditinjau dari faktor eksternal, pada umumnya remaja membutuhkan informasi untuk mengurangi ketidakpastian, memecahkan masalah atau mencari keputusan. Tidak semua kebutuhan informasi remaja tentang gaya hidup terutama fashion dapat diekspresikan, ada juga kebutuhan informasi yang tidak diekspresikan, biasanya mereka mengekpresikannya jika sudah di luar sekolah. Mereka umumnya sudah dapat menyaring informasi yang sesuai dengan kebudayaan dimana mereka berasal.

3. Dalam proses pemenuhan kebutuhan informasi gaya hidup remaja dari faktor internal. Motif siswa dalam memenuhi kebutuhan informasi, biasanya mereka ingin mengetahui informasi apa saja yang sedang hangat dibicarakan. Mereka biasanya mudah mengingat informasi yang telah mereka dapatkan. Rata-rata para informan menggunakan internet sebagai media untuk mencari informasi karena lebih cepat dan para siswa jarang berkunjung ke perpustakaan untuk mencari buku atau hanya sekedar membaca.

4. Dalam proses pemenuhan kebutuhan informasi gaya hidup remaja yang ditinjau dari faktor eksternal, biasanya remaja yang sedang melakukan pencarian jati diri juga menjadi penyebab mengapa remaja bersikap tertututp dalam memenuhi kebutuhan informasinya sehingga lebih suka mencari informasi sendiri dengan menggunakan internet. Hubungan remaja dan orang di sekitarnya juga mempengaruhi remaja dalam memenuhi kebutuhan informasinya. Sedangkan kalau sumber informasi manusia, remaja lebih suka dan memperoleh informasi dari teman 
(kelompok referensi) karena mereka merasa berada dalam nasib yang sama.

\section{DAFTAR PUSTAKA}

Creswell, John W. (2010). Research design: Pendekatan kualitatif, kuantitatif, dan mixed (Achmad Fawaid, Penerjemah). Yogyakarta: Pustaka Belajar

Gunarsa, Singgih D dan Yulia Singgih D. Gunarsa. (2006). Psikologi Perkembangan: Anak dan Remaja. Jakarta: BPK Gunung Mulia

Gunarsa, Singgih D. et al. (1986). Psikologi Perkembangan anak dan Remaja. Jakarta: PT. BPK Gunung Mulia

Hawkins, Del I, Roger J Best, Kenneth A Coney. (1995). Consumer Behaviour: Implication for Marketing Strategy (6th Edition). Chicago: Richard D Irwin Inc

Miles, Steven. (2000). Youth Lifestyle in A Way of Life. London: Open University Pers

Nicholas, Davis. (2000). Assessing information needs: tools, techniques and concepts for the internet age (2nd Ed). London: Aslib

Pakasi, Soepartinah. (1981). Anak dan perkembangannya: Pendekatan psikopedagogis terhadap generasi muda. Jakarta: PT Gramedia

Rahardi, Nopan. (2007). Skripsi: Manajemen Penerbitan Buku Kritis. Fakultas Ilmu Komunikasi Unpad

Santrock, John W. (2003). Adolesence: Perkembangan Remaja. Jakarta: Erlangga

Sugiyono. (2005). Memahami penelitian kualitatif. Bandung: Alfabeta . (2011). Metode Penelitian Kuantitatif, Kualitatif, dan $R \& D$. Bandung: Alfabeta

YIN, Robert.K. (2006). Studi Kasus Desain dan Metode. Jakarta: PT Raja Grafindo Persada

Yusuf, Pawit M. (1988). Pedoman Mencari Sumber Informasi. Bandung: Remadja karya

Agosto, Denise E. dan Sandra Hughes-Hassell. 2005. People, Place, and Questions: an investigation of the everyday life information seeking behaviors of urban young adults". Library and Information Science Research 